\title{
Recent trends in the study of the history of pre-monarchic Israelite religion with particular emphasis on the concept of the covenant
}

\author{
Silvia Linington* \\ (University of South Africa)
}

\begin{abstract}
\end{abstract}
Recent trends in the study of the history of pre-monarchic Israelite religion with particular emphasis on the concept of the covenant

The purpose of this paper is to critically evaluate and compare some of the recent and not so recent works on Israelite history regarding their methodology. Particular emphasis is placed on their treatment of the covenant theme. The time periods under discussion are the primordial, patriarchal and settlement eras.

\section{INTRODUCTION}

\subsection{Preliminary remarks}

The question "[w] hat is truth?" (John 18:38) seems nowhere so pertinent than in the study of Israelite religion(s). For a long time the subject was supplanted wholly or partially by the study of the theology of the Old Testament but now the opposite seems to be the case. However, as von Rad's theology (1975, vol. I) shows, the complex nature of the relationship between the history of religion and the theology of the Old Testament makes it in fact difficult to clearly differentiate between the two. In addition, the political and religious histories of Israel are intricately interwoven, and studies in Old Testament introduction also have an impact on the individual scholar's notion of Israel's religious history. For example, due to the shifts concerning the source history of the Old Testament it has become fashionable to date many texts or concepts (including the covenant concept) late, i.e. to the exilic, post-exilic or even Hellenistic period.

Another important aspect is the worldview and personal agenda of those writing (and reading) histories of ancient Israelite religion, since no one comes to the topic with a tabula rasa. Thus the interpretations and

Postgraduate student, Department of Old Testament (under supervision of Prof W S Boshoff), Unisa. 
evaluations given to archaeological artefacts, the biblical text and to sociological and anthropological research will depend to some (perhaps large) extent on the already present worldview of the writer ${ }^{1}$. Van der Toorn (1998:9-10) has aptly written:

"Considering the nature of the subject, it is not to be expected that the study of religion, whether pursued from a historical or a comparative perspective, will ever set an example of dispassionate scholarly enquiry. Those involved in it always have, in one way or another, a personal stake in the matter. That is why studies of religion are not merely windows on the subject under scrutiny; they also mirror the views and fascinations of the researcher and the researcher's society.... The history of Israelite religion is, ... a field of study that is by nature sensitive to changing ideological needs, styles and fashions.... Despite its importance, ... new [epigraphic or other material] evidence is not commensurate to the shifting modes in the history of Israelite religion. The reason for the ... transformations in the perception of Israelite religion lies at a deeper level: it springs from the fascinations and pre-occupations of contemporary scholars and their audience. Israelite religion caters to the need for a historical model that suits the concerns of the consumers of that model; when these concerns change, the model changes too".

The truth of this observation will be apparent in the following discussion of my own interpretation of a number of different writers.

\subsection{Recent trends in the study of Israelite religion(s)}

In times past studies of Israelite religion were mainly based on the biblical text, with occasional references where appropriate to archaeological research. Recently however, other disciplines like anthropological and sociological studies have become increasingly important contributors to our knowledge about Israelite origins. This is, as McNutt (1999:218) rightly remarks, "an important corrective to the traditional historical reconstructions" of Israel with their emphasis on the political and religious history that naturally tends to deal only with the "official" presentation that the written sources afford. The significance of such neglected aspects as the

1 This, incidentally, is also a point raised by Lemche (1998:50-52, especially $52)$. 
religion of the ordinary folk, the study of the importance of female deities and images in Israel, and the continuity with Canaanite religion has also rightly been emphasised.

Apart from the biblical text itself, archaeological research is today one of the most important foundations for establishing what Israelite religion is all about. In fact, some histories of Israelite religion, for example Keel and Uehlinger's (1993), are now written with an almost exclusively archaeological emphasis. In Keel \& Uehlinger's (1993:4) opinion, "[e]ine Rekonstruktion der Religionsgeschichte Palästina/Israels im 2. und 1. Jt. braucht Primärquellen. Solche aber sind nicht in den biblischen Schriften zu finden, sondern nur von der Archäologie zu erwarten". Others, for example Albertz (1996 and 1997), follow the biblical time periods, yet provide a new emphasis in that they consider the pluralist aspect of Israelite religion.

However, in order to gain a balanced picture of Ancient Israelite religion it is important to look at all the archaeological and the written evidence, including the Bible. I think this is imperative because religion does not only express itself in rites but also, and in my opinion in particular, in words. Therefore, I believe, it is very difficult, if not impossible, to come to conclusions that are more than conjecture about the religion and religious practices of an ancient people unless there are written records concerning such practices. Dearman (1992:41) is correct in observing that "without accompanying texts, the considerable number of figurines and drawings in masculine, feminine and zoomorphic forms remain mute evidence".

Boshoff (2001:387) has rightly pointed out that "Biblical scholars should take the results of archaeological research seriously" and that a "historical consciousness is no luxury which may be employed when the Biblical scholar feels like it. On the contrary. An awareness of the historical nature of theology, texts and interpretation implies that these subjects cannot be studied without thorough historical, and for that matter archaeological, knowledge". In his opinion, the "Biblical text should basically be approached like an archaeological object, which can only be understood well if its context is understood well" (Boshoff 2001:385). In general I prefer this stance to that of scholars who deny the Bible "primary source" value. However, I feel some qualification is justified. It may be one, but certainly not the only valid way to study the Bible. It is after all, 
especially for the Christian, not merely an ancient text, but the Word of God that "is given by inspiration of God, and is profitable for doctrine, for reproof, for correction, for instruction in righteousness, that the man of God may be complete, thoroughly equipped for every good work" (2 Timothy 3:16-17). Nevertheless, a thorough understanding of the historical background of both the Old and New Testament is essential as a safeguard against many a misinterpretation of the texts.

\subsection{The framework of this article}

Representations of Israelite history that are mainly based on archaeological and other aspects, even if they do not neglect the biblical testimony, naturally put less emphasis on more theological concepts like the covenant, the concern of this article. Nevertheless, in order to gain a proper understanding of such theological concepts, it is vital to see them in their context in the development in the history of Israel's religion. Although the order of the historical periods as presented in the Bible is not necessarily that of the history of the text, I will nevertheless follow its general outline into the pre-monarchic era and the united monarchy to the death of Solomon. This seems to me the most satisfactory way to trace the covenant concept in the history of Israelite religion, even though especially the premonarchic period is fraught with problems as far as establishing its development is concerned. The emphasis on the covenant theme also necessitates a greater concentration on the text of the Bible though archaeological research will be considered where appropriate.

\section{THE COVENANT IN THE RELIGIOUS HISTORY OF PRE- MONARCHIC ISRAEL}

"Keine Phase der israelitischen Religionsgeschichte ist mit so vielen Unsicherheiten belastet wie die vorstaatliche Epoche... Das liegt nicht etwa daran, daß für diese Zeit keine Quellen zur Verfügung stünden, eher das Gegenteil ist der Fall... Die Frage ist nur, welcher religionsgeschichtliche Quellenwert [diesen Überlieferungen] zukommt". With this remark Albertz (1996:45) starts his section on the history of the religion of premonarchic Israel. For him, the pentateuchal picture of the early religious history of Israel is most certainly not an accurate representation of the religio-historical development of Israel (Albertz 1996:46), though it is obviously based on the religious traditions of the people. The importance of the biblical literature lies rather in the fact that it presents a historical beginning of the religion and political entity of Israel, in contrast to other 
ancient Near Eastern nations for whom monarchy was inherent in the creation of the world.

The great variety of forms in the history of Israelite religion was already observed by Vriezen (1967). In his opinion, they show a "progressive development in religious thinking" that confronts us "with a process of spiritual growth, a strenuous endeavour to comprehend... God... better", and therefore he wonders "whether we ought to speak of the religion of Israel in the singular at all" (Vriezen 1967:8-9). Zevit (2001) of course emphasises precisely this point, and deliberately entitles his book "The Religions (plural) of Ancient Israel".

It is also difficult to determine when "Israelite religion" began. Many scholars argue that one cannot speak of "Israelite" religion before there was a nation of Israel (for example Vriezen 1967:10) and so the period before the monarchy is sometimes either left out or treated only very briefly. However, the Hebrew Bible depicts the religious history of Israel from the beginning of creation. It is obvious that the tradents of these stories were sure that all the essential elements of the religion of Israel in fact developed since the earliest times of her history even before the possession of the land (see Albertz 1996:46). Therefore it is proper to start with the patriarchal history when discussing the religion of Israel.

\subsection{The pre-historic and the patriarchal periods}

\subsubsection{Religious practices during the patriarchal age}

There is very little extra-biblical evidence of the religious practices during the patriarchal age. However, the names and customs that appear in the patriarchal narratives are similar to those of the first half of the second millennium BCE (Fohrer 1973:31; Bright 1981:47-103) ${ }^{2}$ which seems to indicate that the setting provided by the narrator(s) of the stories is correct. Hess (1998:184), criticising the view that later editors just incorporated the names into stories from different times and places ${ }^{3}$, correctly remarks that

2 This is supported through archaeological finds dated to this era. Bright (1981:77) for example notes that the names of the patriarchs are similar (or even the same) as those found in an 18th century (BCE) text from Chagar-bazar in Upper Mesopotamia. Hess (1998) makes similar observations in his study.

3 Although Hess writes about the Joshua stories at this point, I think the remark is still valid for the Genesis narratives. 
the "antiquity of these names...implies the antiquity of the stories in which they appear, or at least the antiquity of traditions that evolved..."4.

Albertz (1996:52), on the other hand, notes that "das kulturgeschichliche Milieu Palästinas, das die Vätererzählungen Gen 12-50 voraussetzen, nicht über die Verhältnisse der Eisen I-Zeit (ab 1200 v. Chr.) zurückreichen". In his opinion, the Yahweh religion was depicted as a tribal religion whose tradents wanted to tell of the beginnings of the people of Israel which still carried aspects of family religion. To do this they used current ideas of what such family religion would entail, though they possibly still had some actual knowledge of pre-monarchic religious traditions ${ }^{5}$.

Concerning the religion of the patriarchs we can glean the following from the biblical texts. The most important aspects of their religious experiences are the very personal and intimate character of their relationship

4 Lemche (1988:114-115) is critical of this position. In his opinion, "there is no clear chronological horizon for the Near Eastern parallels which have been adduced to the patriarchal narratives" (Lemche 1988:115), though in the previous paragraph he refers to the familial practices of the patriarchs which have some parallels at ancient Nuzi. While he, probably rightly, notes that the correlation of place names which occur in 18th century BCE records with the personal names of some of the patriarchs is questionable methodology, I do not share his scepticism about the possibility of getting information about the patriarchal age from the biblical accounts. It is true that the stories cannot be verified by extra-biblical data; but neither can they be disproved.

5 Lemche (1988:114) also considers the description of the period of the accounts of Israel's history before the monarchy as essentially a later reconstruction of its history by later Israelite society rather than a collection of historical reports. However, he does admit that the traditions of Jacob are already present in Hosea whose activity he dates around $730 \mathrm{BCE}$ and whose prophecies he considers as authentic (Lemche 1988:117). Nevertheless, the most he commits himself to is to say that "certain parts of [the patriarchal tradition] were in circulation in the eighth century BCE. It is probable that certain parts of it may be even older, but there are no contemporary sources which confirm this supposition" (Lemche 1988:117, emphasis his). Thus, in Lemche's opinion the main emphasis of future studies in Israel's historical tradition should be limited to the monarchy because that is when the "the traditions about Israel's past came into being" (ibid). However, while I agree with him that there are no contemporary sources going back to the time of the patriarchal era, the occurrence of references to the patriarchs in the prophets in my opinion indicates that they did in fact not only develop in the monarchy but much earlier. The way these references are used in the prophets do not, I think, indicate new traditions that were being developed but old ones that were utilised to make a point. 
with God (Rowley 1976:34) and the concern with the needs of the family (Albertz 1996:53), for example the need for a male descendant. God is the family God ("God of my father") and communicates in person with the patriarchs. In Albertz' opinion (1996:59) the timeframe between promise and fulfilment is usually very small: just the gestation period of the woman ${ }^{6}$. However, in the Genesis record the fulfilment of the promise of a son sometimes took decades ${ }^{7}$, so the time frame between promise and fulfilment is not always short. I would also disagree with Albertz' (1996: 59) statement that the care of the family God for the survival of the family (in this and other ways) is independent of their moral behaviour. In my opinion, even where the text does not explicitly state it, it is implied that the family members show reverence for God, and thus positive moral qualities. This I think is also proved by the fact that the shortcomings of the patriarchs are not brushed over in the text, though lessons from these are not necessarily explicitly drawn.

\subsubsection{The covenants with Abraham and Noah in current histories of Israelite religion}

The treatment of the covenant theme in the primordial and patriarchal periods differs from author to author in the histories of Israelite religion. In some of the older texts, the topic gets more detailed attention because although the authors write about the history of Israelite religion, they base their research on the Bible and seem generally more theologically orientated (e g Vriezen).

McNutt (1999:41), on the other hand, writing from a sociological viewpoint, does not mention Noah at all and only refers to Abraham in passing. She points out that the stories in Genesis cannot be definitely related to known history in or around Canaan in the second millennium $\mathrm{BCE}$, and thinks that there is no evidence for any date at all. Albertz also

6 This incidentally also shows that the concerns of the woman are important in this kind of family religion.

7 Abraham had to wait 25 years from the first mention of a male descendant to his arrival; Isaac prayed for his wife for 20 years, before she finally became pregnant. Admittedly, in the promise that involved Sarah directly (Gen 18) the time that elapsed from the giving of the promise to its fulfilment was only one year. However, it seems to me that generally the timeframe from promise to fulfilment in this regard was not just the gestation period of a woman (see also Gen 16, where Sarah gives Hagar to Abraham as a surrogate mother for a son). 
never mentions the covenant in his treatment of the patriarchal period. In his work, the covenant with Abraham in Genesis 17 first occurs in his discussion of the exilic period because in his opinion it was during the exile that the focus of religious practice returned from the official cult to the family and circumcision became important (again) because it distinguished Jews from Babylonians who did not normally practise this rite (Albertz 1997:422-423) ${ }^{8}$.

Genesis 15 is generally ascribed to the Yahwist and usually dated in the early monarchy ${ }^{9}$ (Vriezen 1967:109, Fohrer 1973:39-40). Fohrer (1973:39) remarks that the story of the covenant procedure "is based on an ancient tradition, even if we are not dealing with the original words". The relationship established was based on kinship and the deity was perceived as "the head of the clan and could be termed 'father' or 'brother' by its early members" (Fohrer 1973:40). In my opinion this is the key to the understanding of the covenant relationship in the patriarchal period and has not lost any of its pertinence. A similar position is advanced by Miller. He observes that there never was a period in Israel's religious history in which the relationship between the people and God was not expressed in the form of a covenant, even though this relationship may have been understood differently in different historical circumstances and geographical areas. The covenant relationship was not only a political structure but based on kinship relations, whereby "covenant" regulated the way in which someone who was as yet not part of the tribal community was allowed to join it. This naturally included "laws" that regulated the relationships between the members of the community as well as the community and their god (Miller 2000:5-6).

8 Lemche (1988) does not mention the covenants with Noah and Abraham due to his stance that the texts reporting these events are too far removed from the purported original setting of the stories (Lemche 1988:32). In addition, the stories are "not a description of profane, but of religious, history" and "the individual events which are mentioned are not related for their own sake, but because they illustrate the ways the relationship between god and the people changed..." (Lemche 1988:30-31). While these observations are of course true, I do not see them as sufficient reason for simply abandoning any consideration of the biblical texts describing this era completely. That the texts report religious history does not necessarily entail that they are fabricated. And even if the texts are later than the events they report they still seem to report authentic customs, and these it is worthwhile to extract.

$9 \quad$ With probable later expansions from the Deuteronomic School. 
In my opinion, this may explain not only the way covenant operated, but also that covenant could very well be conceived as a very early phenomenon in the religion of Israel. I prefer this view to that of Albertz (1997:508, 512) who considers Genesis 15 even later than Genesis 17, as the work of lay theologians who tried to get to grips with political developments under Persian rule and who considered the promise of the land the most important aspect of the relationship between Yahweh and the people (Albertz 1997:512-513).

The Noahic covenant too is mentioned by Albertz (1997:534) only in connection with the post-exilic re-thinking of theological concepts. He observes that this covenant showed that God was binding himself to his creation, but that it was no longer as immediate a relationship as before the flood. In a footnote he remarks that this is shown by the wording in the Abrahamic covenant: Abraham only walks before God (hithallek lifne Gen 17:1), not with God (hithallek et- Gen 6:9) as Noah did (Albertz 1997:534, note 162). This seems a valid observation, though I wonder whether the word hithallek itself does not point to a close relationship, regardless of the preposition used afterwards, because it may be considered an iterative ${ }^{10}$ stem (see Waltke \& O'Connor 1990:427-429). The question is whether one really has to presume that the covenant concept is a late development in Israel's theology, or whether it could not have developed (and been revealed) earlier ${ }^{11}$.

10 Or, another suggestion, though I am not sure whether it can hold, is that it may in the context mean an intensification, therefore highlighting the closeness of the relationship between Yahweh and the people who are said to hithallek with or before him.

11 I find an interesting parallel in the biblical story of the flood and the Gilgamesh epic. Both relate (see Gen 9 and Dalley 1991:115-116) that after the flood sacrifices are offered. And both relate a special relationship between the deity and the man in question. In the Bible, God makes a covenant with Noah, in the Gilgamesh epic, Utnapishtim and his wife gained immortality. Maybe this could be considered as something like the covenant that is given in Genesis, though of course the word is not used in the Gilgamesh epic. The point is that covenant need not be altogether a late development in the theology of Israel. 


\subsection{The mosaic period: The Sinai covenant}

\subsubsection{General remarks}

The exodus and wilderness wanderings are probably the most important events in the history of Israel, when, according to her own witness, Israel became a nation, though as yet without a land and proper identity. It was also the first time that the relationship between Israel and Yahweh was stated in the terms "I am your God, you are my people", and regulated by way of stipulations and law. Yet this time is also one of the most disputed areas in biblical scholarship. There is a lack of consensus concerning the origin and date of these accounts, and indeed questions have been raised whether these events took place at all, as there is no archaeological or other extra-biblical evidence to support them ${ }^{12}$. This lack of agreement should caution one against hasty conclusions on these issues. Dever (Shanks et al 1992:31) aptly remarks that "the traditional notion of Moses receiving the Law at Sinai is not a story that we can comment on archaeologically.... [B]ehind the literary tradition there must indeed be some sort of genuine historical memory; but it is unfortunately not accessible either to the text scholar or to the archaeologist". The following is based on the biblical account as interpreted by Albertz and other scholars.

\subsubsection{The religion of the Exodus group}

Albertz (1996:68-104) calls the religion of the Exodus group the "Religion der befreiten Großgruppe", in which the focus is more on political issues (Albertz 1996:74), and the relationship between the people and the deity is no longer described as close and intimate as that in Genesis. For example,

12 Lemche (1988) in chapter 3 on the pre-monarchical period for example does not mention it at all, since it is not mentioned in extra-biblical sources. In a later work he is even more extreme: "The exodus has a long time ago passed from history into fiction. It never happened. Neither did the conquest ever happen" (Lemche 1999, para 8.4).

Barstad (1997:56-57) considers the exodus as a myth, not a report of what Israel's history really looked like. This and other myths are in his opinion part of the reconstructed history of Israel by later historians to cater for the need of a national history of the nation in a style similar to Icelandic sagas. 
the group needs a mediator in order to communicate with $\mathrm{God}^{13}$, and we are no longer told of the personal sacrifices of individuals without a mediator. However, there is also a clear continuation from the religion of the patriarchs to that of the exodus group (cf Exod 2:24), and unlike gods elsewhere in the ANE, Yahweh commits himself to a whole people and not just a town or a king (see Albertz 1996:78). He acts on their behalf and is concerned for their interests as a nation.

With the increasing size of the group, a new type of public worship developed where the familial sacrifices where everyone could offer gifts to the deity were abandoned in favour of an elaborate cultic system which only allowed certain people to come into close contact with God. Albertz (1996:80) notes that the relationship between God and the Exodus group was far more dependent on human decisions and actions than in the patriarchal era where the relationship between God and the family of the patriarch was one of mutual trust. I beg to disagree with this notion. As at Mt Sinai, faith was also required of Abraham (see Gen 15). And from Numbers 11:29 it seems obvious to me that God's desire had always been to have an intimate and close relationship with each person belonging to the covenant community. The very fact that stories of intimate contacts between one person (Moses, Joshua, David, the prophets) and Yahweh are told also indicates this.

\subsubsection{Scholarly views on the covenant concept as depicted in the books of Exodus and Deuteronomy}

Although the formal similarities between fourteenth century BCE Hittite treaties and the Sinai covenant have been noted by many scholars, the question of whether or not the relationship between Israel and Yahweh at Mt Sinai can be termed "covenant" continues to be debated. Fohrer (1973:80) for example denies it, thinking that the word $b^{e}$ rith means "promise" or "obligation", rather than "treaty", "covenant" or "contract". Thus he considers a relationship between the Sinai covenant and the Hittite treaty forms as untenable.

A similar view is expressed by Albertz (1996:103). In his opinion, Israel's early history was not based on a covenant. He believes that the

13 When the law is given at Mt Sinai, the people ask Moses to receive it for them from God, and that they will do what Moses says, but they do not wish to relate to God directly (Exod 20:19, also 24:1-2). 
concept was only developed much later and then transferred back into history. According to him, one can speak at most about a particular personal relationship between Yahweh and the Exodus group, which advanced the social integration of the group at the time. He regards the Sinai covenant as a development of Deuteronomist theologians who took their cue from Assyrian treaties that Israel had just experienced herself (Albertz 1996:357). Albertz (1996:349) notes that the Deuteronomists not only created "überhaupt den ersten begrifflich und gedanklich durchstrukturierten theologischen Gesamtentwurf der Jahwereligion", but they also were the first to declare that they were writing an official theology for all Israel, not just for one group within the nation. In going back to the beginnings of Yahweh's history with the people, they offered all the groups in their society an integrative theological basis (see Albertz 1996:350). They presented the picture of a unified and connected history of Israel's beginnings in which the whole of Israel had a part, using two important theological terms, election (bachar) and covenant ( $b^{e}$ rith). By reinterpreting the old traditions and including most of the laws in the covenant, the theologians were able to combine in one theological concept, the covenant, the whole relationship between Israel and her God in the past and present history (Albertz 1996:358-359).

While Albertz' view makes sense in the way he presents it, I beg to disagree with regard to his late dating of the covenant concept. It seems to me that to speak of the special relationship between Yahweh and the Exodus group as he does, yet without using the word covenant, may be possible, but avoids the issue. I prefer Ringgren's opinion that "the possibility of Mosaic origin must be considered seriously". In addition, "[ $t]$ he fact that the present form of the Sinai narrative in all probability goes back to a north Israelite source does not prove the contrary, since the form of a tradition is not the determining factor in deciding its origin" (Ringgren 1966: 36, emphasis mine). That the Deuteronomists used the covenant concept to present their theology also does not, I think, necessarily mean that they were the ones who first used it. They might just as well have taken it over from earlier traditions and expanded and adapted it.

Ringgren also observes that while one cannot say definitely to what extent the covenant idea goes back to Moses, it is nevertheless a very old conception basic to Israelite religion, and because of the similarities between the fourteenth century Hittite treaties and the Sinai covenant, the covenant concept of the Bible is not necessarily a late idea (Ringgren 
1966:36) ${ }^{14}$. Since such vassal treaties would have been well known all over Syro-Palestine for centuries from the political sphere, it is not surprising that the form was adapted to the religious realm in Israel (see Mendenhall 2001:55-69). I consider this view more likely, in particular because I have reservations about the rather one-sided interpretation of the meaning of the word $b^{e}$ rith as "obligation" or "promise". I think that there are contexts where the word does not only entail obligations or promises, but can be conceived of as treaty, covenant or contract, even in the religious realm, as I have tried to show elsewhere (see Linington 2002 and 2003).

\subsection{The emergence of Israel in Canaan - Joshua and Judges}

\subsubsection{Theories of the emergence of Israel in Canaan and its social structure at the time}

The question about the emergence of Israel in Canaan is a vexed one and will probably continue to be debated "forever, or at least until Elijah returns to clear up such matters, among other somewhat larger duties he is to perform" (Freedman 1987:317, admittedly in a slightly different context). The models formerly proposed by scholars (conquest, associated with Albright; peaceful infiltration, associated with Alt; internal revolt, associated with Mendenhall and Gottwald ${ }^{15}$ ) are increasingly considered as insufficient to explain the emergence of Israel in Canaan. The picture painted in Joshua and Judges is obviously very much idealised, and archaeological evidence relating to the period is not conclusive and does not seem to support the picture of a conquest. Destruction layers found at several places in the Holy Land used to be taken as confirmation of a (partial) conquest during about the $13^{\text {th }} / 12^{\text {th }}$ century BCE (see e.g. La Sor et al 1982:203), although there were problems with this view. For example, at Jericho, destruction layers were found for the $15^{\text {th }}$ century, but neither occupation nor destruction for the $12^{\text {th }}$ century (La Sor et al 1982: 203, see also Kenyon 1970:209-212).

14 See also Fensham (1963:138-140 and 1963:141-142). Lemche (1988:236-37) accepts the view that the Sinai covenant as presented in Dt has more affinities with Assyrian vassal treaties of the first millennium BCE. This is the time considered as the background for the framing of the deuteronomistic theology; thus he seems to deny that there is any basis for a Sinaitic covenant.

15 For a description and critique of these models see for example Lemche (1996:10-16). 
Recent archaeological discoveries and their interpretation seem to render this opinion even more problematic. Dever (Shanks, Dever, Halpern \& McCarter 1992:32) for example opines that "there is not a single destruction layer around $1200 \mathrm{BCE}$ that we can ascribe with certainty to the Israelites". Similar sentiments are voiced by McNutt (1999:42-44, 46$51)$. McNutt is only willing to commit herself to "a major cultural shift in Palestine between the end of the Late Bronze Age and the beginning of the Iron Age I" as well as "a major social transformation ... [and] a significant increase in the number of occupation sites in the central highlands" (McNutt 1999:47). She (1999:78) and Albertz (1996:116-117) are among many who think that the description of the whole pre-state system as a segmented society seems to fit the biblical and archaeological records best.

Lemche (1988:88-105) outlines the structure of the tribal society in Palestine before and around the period of the judges in terms of everwidening circles of interrelationships between the people of a particular area, starting with the individual and his family, then the extended family, the lineage, the clan and finally the tribe. These relationships were not necessarily determined by blood-relationships, though these were important too, but more by physical proximity. However, Lemche (1988:101) admits that there are practically no data to verify the precise structure of that society. Then he proceeds to present his own hypothetical model of the period, which he bases on experience of relationships in modern traditional peasant societies. As far as his evaluation of Israelite religion is concerned, for him, at least during the monarchy, but by implication also in earlier periods, it was not significantly different from that of the surrounding peoples ( $\mathrm{cf}$ his conclusion in 1988:256-257). This difference only emerged during and after the exile.

What is clear from the above is that all the present models describing the era of Israel's emergence in Canaan are based on speculation and hypotheses. Depending on the preconceptions of the scholar concerned, the biblical account is considered as more or less unreliable in gaining any information concerning this period, yet archaeological and other information is also scarce. Thus, an evaluation of its religious developments is extremely difficult, though everyone speculates in one form or another about it. It seems to me that perhaps an approach that would seek a compromise in combining the different models might lead to more satisfactory results in the future. What follows is based on the assumption that despite the fact that the texts are far removed from the time they report, we can 
indeed glean some information from the biblical texts concerning the religion of this era.

\subsubsection{The religion of Israel in the time of the judges}

In the Bible, the religious experience of the people during the time of the settlement is depicted as one of continued apostasy from Yahweh, a time where "everyone did as he saw fit" (Jdg 21:25). It might be described as a time of religious pluralism, with many accepted forms of worship that were directed at different gods and goddesses, as the scant archaeological evidence indicates. This is hardly surprising, given the population mix that apparently existed at the time, whose different sectors would all have contributed their own religious ideas to their society.

Keel and Uehlinger have investigated seals relating to Iron Age I and found that goddesses at that time were no longer depicted in anthropomorphic form (Keel \& Uehlinger 1992:148). At the same time the seals do not point to any evidence regarding the worship of Yahweh in Iron $\mathrm{I}^{16}$. Albertz (1996:144-45) notes that personal names continued to be formed with components other than Yahwistic ones, and that they rarely referred to the historical past. Thus he infers that the historical happenings had almost no importance in the private sphere, where the people had their own personal experiences with their god(s). Dever (1987:233) observes that "there is nothing in the archaeological record per se that reflects 'Yahwism' - or, indeed, any distinctive new Iron I ideology...”. Both the Bible's negative judgement of this heterodox form of religious practice and external sources thus show that worship in pre-monarchic Israel was not uniform or directed at just one deity. Indeed, there seems to have been a far greater variety than even its critics who wrote the biblical text perceived.

Because Joshua and Judges are generally dated far later than the events they describe, many scholars consider these books unreliable for establishing the "real facts" of what actually occurred at the time. It is of

16 Smith (1987:17) observes that the names of Judean and Israelite kings only start to be compounded with Yahweh after Asa, who named his son "Jehoshaphat" (Yahweh judged). From this he surmises that it is from this period only that there was a demand that all Israel worship only Yahweh, while before this time it was obviously common to worship other gods besides Yahweh as well. He remarks that in most cases where Yahweh sanctuaries were established in the land, "there is no evidence that the cults of the other gods have been extirpated from these sites" (Smith 1987:15). 
course debatable whether anyone ever can really write a history of "how it actually happened"17. However, with reference to the pre-monarchic history of Israel, there are texts in the Bible apart from Joshua and Judges that may be dated early, perhaps reaching back to the exodus and settlement period, and which may therefore give clues concerning the religious practices of the time when they were written. Freedman (1987) has studied five of these earliest materials of the Bible (Gen 49; Exod 15 ${ }^{18}$, Num 23-24; Dt 33 and Jdg 5). For my purposes, the following remarks will suffice.

In a brief discussion of Judges 5, Freedman (1987:333-334) notes that the poem in this chapter reflects the completion of the conquest, but otherwise he unfortunately does not elaborate on this particular text. $\mathrm{He}$ generally opines that all the poems he considers have been composed in substantially their present form in the premonarchic period and therefore provide important information regarding the earliest phases of Israel's religion (Freedman 1987:333). He dates Genesis 49 in the period of the judges (though the tradition it refers to is earlier, pre-mosaic), which in his opinion is shown by its archaic language, the presentation of the tribal grouping and the peculiar description of the tribe of Levi. Freedman (1987:325) even finds an allusion to a consort of El in Genesis 49:25 in the expression "Breasts and Wombs". However, in my opinion this seems a rather implausible interpretation of the text. I think it is more natural to interpret the blessings of the breasts and wombs as part of the blessings that are given from heaven above and the depths below, not as a veiled reference to a female deity ${ }^{19}$.

17 See for example the article by Provan (1995) on this very issue.

18 Albertz (1996:200-201, note 27) however denies the antiquity of Exod 15, because in his opinion verse 17 presupposes the theology of the Jerusalem temple and is an attempt to combine Exodus- and Zion-theology, which he thinks is most plausible as coming from Josiah's days.

19 This does not detract from the fact that Freedman's (1987:325) re-division and re-pointing of the words makes sense. The chiasmus I think can still hold, but the middle section -

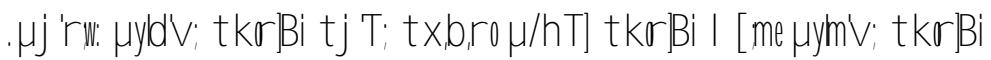

- outlines what kind of blessings there are: blessings of heaven and earth, i.e. fruitfulness in all aspects, including fertility of the family. In my opinion it does not refer to gods. 


\subsubsection{Religionsinterner Pluralismus and other features of the religion of Israel during the settlement period}

According to Albertz (1996:123-127) one of the most important religious experiences of the people in the time of the judges was the help of Yahweh in war, an experience which he terms "wars of Yahweh". Here the people encountered the help and support of their God in the historical-political realm, just as during the Exodus. These wars are not depicted as conquering other nations but as liberation wars that were fairly limited as far as space and manpower were concerned. Such wars were only fought when there was a sufficient economic or political need. Yahweh's power was seen in the fact that the tribes were united in war and the spirit of Yahweh is depicted as having inspired the military leaders. Generally, these leaders, termed judges, did not come from backgrounds of significant social standing, but they were just at the right time called by Yahweh for their particular task. Also, Yahweh gave military tactics that were successful in warfare.

It is in this period that Albertz (1996:144) for the first time mentions "religionsinterner Pluralismus",20, which means a variety of religious practices among the people of one faith at any one time. In the pre-monarchic period, personal piety was still practised in the old way, relatively uninfluenced by the new national religion. Although in the cult of the group Yahwism became more and more important, there was as yet no central sanctuary ${ }^{21}$. Rather, worship was as decentralised as the political structure of the people, with many high places (bamoth) and few, if any, temples. Only later did Shiloh become a more prominent place of worship. The structure of worship at this time is difficult to infer, but it is reasonable to assume that sacrifices were offered, presumably by the father of the family, not just the priest. There seem to have been three yearly (probably originally agricultural) feasts, of which Tabernacles would have been the most important. Yahwism was primarily related to the experience of the people with him in the political-historical realm, though this did not of course exclude that he would also be related to the land, in common with ancient Near Eastern ideas. In fact, this latter aspect became so prominent,

20 This term was first used by G Lanczkowski (1971). Begegnung im Wandel der Religionen, not available to me, cited by Albertz (1978:11).

21 Contra the amphictyony thesis of Noth (1965:91). 
that the prophets later had to denounce it as apostasy to Baal (see Albertz 1996:127-142).

While covenant is not mentioned at all by Albertz in his treatment of the settlement period, Fohrer (1973:100), points out that during this time the Sinai $b^{e}$ rith was "no longer something to live by" and therefore the concept "took a back seat" - at least in private religion. What counted was to "maintain and nurture the outcome of the Sinai event: the permanent association between Yahweh and Israel" (Fohrer 1973:100, italics mine), which would have been a matter of "public" religion. This happened through the cult and by retaining kinship relations, which defined all of what was now considered Israel as the people of Yahweh. The fact that there are only few occurrences of the word $b^{e}$ rith (apart from the phrase Ark of the Covenant) in Joshua and Judges and the archaeological record seems to corroborate this.

Miller (2000) differs from Albertz in his opinion concerning the age of the covenant idea, and I find his reasoning convincing. He notes that "[t]he close relationship between deity and tribe or tribes was rooted in kinship relations and historical experience. It expressed itself in covenantal forms, at the heart of which was a binding together of the people in a sociopolitical relation with the deity that recognized the involvement of Yahweh in the guiding and protecting of the people and that obligated them to maintain allegiance to him, adhering to various stipulations that served to order their life and their relationship to other social groups or peoples" (Miller 2000:4; see also Fohrer 1973:97-98). As far as the biblical texts are concerned, I agree with Miller's statement that "[ $t]$ here does not seem to have been any period in Israel's religious history where the specific recognition of the relation of deity and tribe or people was not expressed in such a [covenant], though it took different forms prior to the monarchy and during it and may have been understood or formulated differently in the North and in the South. In its simplest form, which is not necessarily the earliest, that covenantal bond rested in the reciprocal claim and promise of Yahweh, 'You are my people', and of Israel, 'You are my God (Hos. 2:25 [23])' (Miller 2000:5).

The development of family religion together with official religion was, according to Miller (2000:6) aided by this concept of covenant between Yahweh and Israel precisely because it was not just a political structure but a kinship relationship that had been established. "If rela- 
tionships in ancient Israel were first of all governed by kinship ... so that family and tribe were the central social units, the covenant was the legal way of effecting what Cross has called 'kinship-in-law'. That is, covenant was the mode whereby someone or some group not part of the kinship unit was brought into it, a legal means of creating a new kinship bond between persons".

The memory that Joshua 24 relates of a covenant ceremony at Shechem may in fact be such an occasion. It also, I think, would explain how and why the experiences of the Exodus group and other encounters that happened originally only to one or a few groups were later extended to the other tribes as well, as Albertz (1996:111) remarks. It may moreover explain to some extent the easy acceptance of the equation Yahweh equals El, when the Exodus group joined other groups in the heartland of Canaan $^{22}$.

\section{CONCLUSIONS}

In this article I have tried to trace some of the recent trends in recent scholarship regarding research into the history of Israelite religion in the pre-monarchic period. One of the scholars whom I have examined extensively in my survey is Albertz. While I generally find his arguments convincing, or at least plausible, I do have doubts about his rather enthusiastic statements concerning the late dating of many incidents, in particular the covenant concept, which he only perceives as developing in the exilic and post exilic period. It seems to me that Albertz relies too heavily on the research of Blum, who favours a late dating for many texts that used to be dated far earlier. However, the complexity of the interplay between oral and written tradition that Niditch (1997) very well demonstrates, and the complex history of the text as a whole does in my opinion stand in the way of a "precise" dating of the sources as advocated by Albertz and before him Blum.

I think that C S Lewis' caution against putting too much faith in the results of critical analysis is applicable in this case too. He said (quoted in Wenham 1979:8, note 3): "The 'assured results of modern criticism', as to the way in which an old book was written are 'assured' ... only because the men who knew the facts are dead and can't blow off the gaff'. With

22 Cf also the different, but very interesting reasoning of Albertz (1996:117122). 
regard to late dates Keel and Uehlinger (1992:473) also warn against arriving at hasty conclusions when they note that "neither a mosaic monotheism nor some of the favoured late and latest datings are indicated by the external evidence" (my translation). Thus in my opinion caution is in order with regard to the conclusions that Albertz draws concerning the time when the theologians of Israel came to the understanding they did about the covenant concept. I also believe that even if the extant texts were late, this is no reason to assume that the theological concepts depicted need necessarily be equally late in development ${ }^{23}$.

On the contrary, with regard to the covenant idea, covenants would be well known in the political and private spheres of the people at an early age, even if, as Fohrer (1972:39) noted, the very words were not used. Therefore, it is not inconceivable that the concept was also transferred to the religious realm fairly early. In addition, conclusions about the late dating of the covenant concept do not take account of divine inspiration that may well have given people insights far earlier than one would normally give them credit for. I think it perfectly possible that the tradition of a covenant between God and the patriarchs is one of them. Therefore, while the finer theological points may only have received proper understanding later, the basic concept of a covenant as representing a relationship is in my opinion early.

The religious developments during the exodus, the wilderness wanderings and the conquest of the land have been well described as "religionsinterner Pluralismus" by Albertz. No matter what one thinks of the reliability of the biblical texts, both scripture and archaeological evidence point to a multiplicity of accepted religious practices during that time. The former of course includes value statements concerning these practices that are beyond the scope of archaeological reports.

23 A similar argument is advanced by Provan (1995:598), where he argues that "one could never argue logically from the mere distance of a text from the events it describes directly to its usefulness as historiography or otherwise. It is amazing that modern scholars, themselves twenty-five hundred years or more distant from the events they seek to describe, should risk advancing such an argument at all amazing, that is, if they themselves have aspirations to be taken seriously as portrayers of the past and do not wish simply to be regarded as novelists". (emphasis his). 
In conclusion, a few comments about the growing scepticism among some scholars regarding the reliability of the biblical text as historical evidence are in order. I must say that I do not share the scepticism of many of these scholars, though I find a number of points where I agree with them, as will be obvious from the remarks below. While I cannot deny that there are problems involved in retaining a positive view of the reliability of the biblical witness as historically accurate, my basic presuppositions are obviously very different from scholars such as Lemche.

One of the issues at stake is what kind of value, if any, the Bible has in historical research. Is it accorded primary, secondary or even only tertiary source value? Depending on the period under consideration, and also one's view about the source history of the Bible, different answers may be given to this question. Concerning the primeval and patriarchal eras, probably all (even conservative) scholars would agree that since the reports are far removed from the time they were written down, the biblical report represents a secondary source. However, for the remaining periods, the issue is different. Conservative scholars would argue that most of the material goes back to eye-witness sources, written down soon after the events reported happened and then passed on, both orally and in writing, to further generations. This is by no means impossible since Moses is described as a man educated at the Egyptian court, and so he would have been familiar with writing and he also would have had the intellectual capability to compose the Pentateuch. That other people among the Israelites were able to write is also quite plausible.

Against this is of course the source history of the Pentateuch advanced from the time of Wellhausen and modified and refined ever since. This places the earliest writings in the time of the early monarchy, though more radical schools of thought deny even that and date almost all the Old Testament material in the post-exilic and even Hellenistic era. If one adopts this view, of course the whole of the Old Testament is to be regarded as a secondary source at best and as historically completely unreliable at worst. I certainly do not share this very extreme view, simply because the evidence does not in my opinion corroborate it. There are texts in the Bible that can be dated very early, and one should not confuse the final redaction (of which our earliest examples are indeed only from the third or second century BCE) with the history of the text as a whole. However, I also have my doubts about the documentary hypotheses. While I agree that the texts were edited and re-edited numerous times in their 
history, I find it perfectly possible that they do go back to eyewitness accounts of the periods whose history they purport to tell. Admittedly, it is difficult, if not impossible to prove which of the accounts one would consider those of eyewitnesses and which are embellishments of later editors - but neither can the other purported textual histories be proved beyond doubt. Smith (1987:15) would reply to this: "That a story is possible is no proof that it is true; late inventions may resemble early facts". I would counter by arguing that if one cannot prove that something has happened, this does not mean that it never happened.

Another question concerns the method of history writing. All historians select their materials carefully for their purposes ${ }^{24}$, interpret them according to their particular emphases ${ }^{25}$ and present them in logical sequences, which in itself is also an interpretative process. Another important factor to consider is that all pictures of Israel's history - biblical as well as those derived from archaeological and other research - are interpreted pictures, and research based on extra-biblical methods is just as subjective as the biblical presentation. Even the history of Israel as it is presented in today's works on the subject leaves many questions open ${ }^{26}$, and I think Hesse's use of the word "mutmasslich" is quite in order to describe this fact $^{27}$.

24 This is evident even in the Bible; cf the different approaches taken by the writer(s) of the deuteronomistic history and the Chronicler's history.

25 Von Rad (1964:393) notes: "Bruta facta gibt es ueberhaupt nicht; wir haben die Geschichte immer nur in Gestalt von Deutungen, nur in der Spiegelung". In other words, the history of Israel today deals with the interpretation of the facts, if only because it is often impossible to find the facts since the only extant material at the disposal of the historian is the ancient interpretation of those facts (cf also Hesse 1969:11-12). Hesse (1969:14-15) remarks that no-one just states a "nude fact", even though it is behind any interpretation of this fact. Giving the example of David's census, he observes that modern and biblical interpretation of the facts differ in that the former looks to the motives that occasioned the census, while the biblical interpretation is more interested in the immediate effect of the census.

26 Cf McNutt (1999:46), who observes with regard to archaeological records concerning the emergence of Israel in Canaan that "...tracing the origins of ancient Israel in the archaeological record also poses difficulties. The material evidence has proved ambiguous and inconclusive...".

27 Hesse (1969:3) says: "Die Geschichte der Taten Gottes, wie sie sich Israel selbst darstellte, wie sie sich darum im alttestamentlichen Zeugnis niedergeschlagen hat, ist etwas voellig anderes als die Geschichte Israels, die sich nach der uns 
Related to the previous point, but nevertheless distinct from it, is the type of literature the Old Testament represents. While the Old Testament contains historiography, it is not in the first instance to be seen as a historical, but as a theological book. The biblical writers wrote about God's dealings with mankind. Therefore, they saw and wrote history from the divine perspective, unlike modern history writing that leaves out the divine because it is unverifiable. Thus they omitted much information that we would regard as essential in writing a "history of Israel". In addition, the style adopted for the reporting of historical events in the Bible, narrative, is usually considered incongruous with history writing, since it is considered unverifiable. Barstad (1997) has made some very valuable arguments in favour of considering biblical narrative history as a valid form of history writing, though I do not agree with all his conclusions ${ }^{28}$.

The argument against the Biblical text on the ground of its ideological bias does also not mean one cannot gain accurate information from it ${ }^{29}$. In my opinion, no history of Israel (or any other country for that matter) is ever entirely "un-ideological" (if such a word exists). Thus, even if the biblical account is biased or contains miracles ${ }^{30}$, this does not indicate that the events related have not happened, or are not true accounts. Rather, it seems similar to the accounts witnesses give in court, each one

gegebenen Einsicht in die Zusammenhaenge geschichtlicher Ablaeufe mutmasslich im palaestinensischen Raum abspielte".

28 Especially the relegation of much of the material to the category of "myth".

29 It is interesting that Lemche (in Grabbe, 1997:140, n 25) makes a similar statement: “...the ideological framework of the Old Testament historical narrative certainly does not exclude the possibility that historical information is concealed in this narrative. On the other hand, if we do not respect the intentions of the author(s) of the so-called historical literature in the Old Testament ... and limit our critical investigations to only a rationalistic paraphrase of this story after having removed selected parts of the narrative..., then we have not only destroyed a marvelous narrative, but we have also lost our ability critically to distinguish between history and narrative and thus to reach any historical conclusions worth speaking about". It is obvious that he too is willing to accept biblical evidence to some extent - though to a far lesser degree than I would do. The basic difference is, I think, the view one has of the biblical text: if, as I do, one regards it as divine inspiration, one will place more trust in it than if one considers it merely a construct of human activity and nothing else.

30 Miracles are dismissed as unhistorical by many scholars. Again, I question the presuppositions behind this. The mere fact that we cannot prove them does not in my opinion mean that the miraculous events reported never occurred. 
adding another perspective. In the same way, archaeological (and other) evidence supplies more details to the compressed stories of the Bible and provides different and additional information that enlarges our picture of ancient Israelite society and religion.

Furthermore, I think that much will hinge on how the archaeological evidence and the Bible are interpreted. Lemche (1999, para 9.1) points out that "archaeology is not an exact science like mathematics and never will be. Any result obtained by an archaeologist will include a number of hypotheses ... based on the material he ... has found". In addition, archaeological excavations result in the destruction of the evidence, thus "the original archaeological situation can never be re-established" (ibid.). In other words, extra-biblical disciplines will also only be able to give part of the picture - perhaps a much smaller part than one would like to admit and the "real truth" will obviously never be fully forthcoming (at least this side of eternity). There is still much that we do not know, and one would do well to be cautious in dismissing one part of the evidence, which the biblical text doubtless represents.

\section{Consulted literature}

Albertz, R 1978. Persönliche Frömmigkeit und offizielle Religion. Religionsinterner Pluralismus in Israel und Babylon. Stuttgart: Calwer Verlag (Calwer Theologische Monographien).

-, 1996. Religionsgeschichte Israels in alttestamentlicher Zeit, Bd. 1, 2. Aufl. Goettingen: Vandenhoeck \& Ruprecht (ATD Ergaenzungsreihe, Band 8/1).

-, 1997. Religionsgeschichte Israels in alttestamentlicher Zeit, Bd. 2, 2. Aufl. Goettingen: Vandenhoeck \& Ruprecht (ATD Ergaenzungsreihe. Band 8/2).

Barstad, H M 1997. History and the Hebrew Bible. In: Grabbe, L L, (ed.) Can a 'History of Israel' Be Written? Sheffield: Sheffield Academic Press, 37-64 (JSOTS 245).

Boshoff, W 2001. Archaeological publications and the history of Ancient Israelite religions. Primary and secondary publications on the archaeology, history and religion of ancient Israel. Old Testament Essays 14(3), 371-391.

Bright, J [1981] 1991. A History of Israel, ( $3^{\text {rd }}$ ed.). London: SCM Press.

Dalley, S (translator) 1991. Myths from Mesopotamia. Creation, The Flood, Gilgamesh and Others. Oxford, New York: Oxford University Press (World's Classics).

Dearman, A J 1992. Religion and Culture in Ancient Israel. Peabody, Massachusetts: Hendrickson. 
Dever W G 1987. The Contribution of Archaeology to the Study of Canaanite and Early Israelite Religion. In: Miller, P D Jr.; Hanson P D; McBride S D; (eds.) Ancient Israelite Religion. Essays in Honor of Frank Moore Cross. Philadelphia: Fortress Press, 209-247.

Fensham F C 1963. 'Clauses of Protection in Hittite vassal treaties and the Old Testament.' VT 13, 133-143.

Fohrer, G 1973. History of Israelite Religion, London: SPCK.

Freedman, D N 1987. 'Who is like Thee Among the Gods? The Religion of Early Israel.' In: Miller, P D Jr.; Hanson P D; McBride S D; (eds.) Ancient Israelite Religion. Essays in Honor of Frank Moore Cross. Philadelphia: Fortress Press, 315-335.

Grabbe, L L (ed.) 1997. Can a 'History of Israel' Be Written? Sheffield: Sheffield Academic Press (JSOTS 245).

Hess, R S 1998. Issues in the Study of Personal Names in the Hebrew Bible. Currents in Research: Biblical Studies. CR: BS 6, 169-192.

Hesse, F 1969. Bewährt sich eine "Theologie der Heilstatsachen" am Alten Testament? ZAW 81, 1-18.

Keel, O \& Uehlinger, C 1992. Göttinnen, Götter und Gottessymbole. Neue Erkenntnisse zur Religionsgeschichte Kanaans und Israels aufgrund bislang unerschlossener ikonographischer Quellen. Freiburg, Basel, Wien: Herder (Quaestiones Disputatae 134).

Kenyon, K M 1970. Archaeology in the Holy Land. ( $3^{\text {rd }}$ ed). London: Ernest Benn Ltd.

Knight, D A \& Tucker, G M (eds.) 1985. The Hebrew Bible and its modern Interpreters. Philadelphia, Pennsylvania: Fortress Press. Chico, California: Scholars Press.

La Sor, W S; Hubbard D A \& Bush, F W 1982. Old Testament Survey: The Message, Form, and Background of the Old Testament. Grand Rapids, Michigan: Eerdmans.

Lemche, N P 1988. Ancient Israel. A New History of Israelite Society. The Biblical Seminar. Sheffield: JSOT.

-, 1996. Early Israel Revisited. CR:BS 4, 9-34.

-, 1998. New Perspectives on the History of Israel. In: Garcia Martinez, F \& Noort, Ed, (eds.) Perspectives in the Study of the Old Testament and Early Judaism. A symposium in Honour of Adam S Van der Woude on the Occasion of His $70^{\text {th }}$ Birthday. Leiden, Boston, Köln: Brill, 42-60 (VT Supplements vol. LXXIII).

-, 1999. On the Problems of Reconstructing Pre-Hellenistic Israelite (Palestinian) History. Address to symposia at the University of Aarhus, Denmark, in September 1999 and Columbia University, N.Y. in November 1999. Internet version: 
http://collection.nlc-bnc.ca/100/201/300/journal hebrew/html/1996-2000/1017/Articles/article 13.rtf

Linington, S 2002. 'The term tyr B] in the Old Testament. Part I. An enquiry into the meaning and use of the word in the contexts of the covenants between God and humans in the Pentateuch.' OTE 15(3), 687-714.

-, 2003. 'The term $t y r B$ in the Old Testament, Part II, An enquiry into the meaning and use of the word in the prophetic literature (Isaiah, Jeremiah, Ezekiel and the Book of the Twelve).' OTE 16(2), 259-290.

McNutt, P 1999. Reconstructing the Society of Ancient Israel. Library of Ancient Israel. Louisville, Kentucky: Westminster John Knox Press/London: SPCK.

Mendenhall, G E 2001. Ancient Israel's Faith and History: An Introduction to the Bible in Context. Louisville-London-Leiden: Westminster John Knox Press.

Miller, P D Jr.; Hanson P D; McBride S D (eds.) 1987. Ancient Israelite Religion. Essays in Honor of Frank Moore Cross. Philadelphia: Fortress Press.

Miller, P D 2000. The Religion of Ancient Israel. Library of Ancient Israel. Louisville, Kentucky: Westminster John Knox Press/London: SPCK.

Niditch, S [1996] 1997. Oral World and Written Word. Orality and Literacy in Ancient Israel. Library of Ancient Israel. London: SPCK.

Noth, M 1965. The History of Israel ( $2^{\text {nd }}$ English ed.), London: Abraham \& Charles Black.

Provan, I W 1995. Ideologies, Literary and Critical: Reflections on Recent Writing on the History of Israel. $J B L$ 114(4), 585-606.

Ringgren, H 1966. Israelite Religion ( $2^{\text {nd }}$ corrected impression). London: SPCK.

Roberts, J J M 1987. In Defense of the Monarchy: The Contribution of Israelite Kingship to Biblical Theology. In: Miller, P D Jr, Hanson P D, McBride S D (eds.) Ancient Israelite Religion. Essays in Honor of Frank Moore Cross. Philadelphia: Fortress Press.

Rowley, H H [1967] 1976. Worship in Ancient Israel: Its Forms and Meaning. London: SPCK.

Shanks, H; Dever W G; Halpern B; McCarter P K Jr. 1992. The Rise of Ancient Israel. Washington DC: Biblical Archaeology Society.

Smith, M 1987. Palestinian Parties and Politics That Shaped the Old Testament $\left(2^{\text {nd }}\right.$ edition). London: SCM Press.

Van der Toorn, K 1998. Currents in the Study of Israelite Religion. In: Hauser A J; Sellew P \& Watson D F, (eds), Currents in Research. Biblical Studies. CR: BS 6, 9-30.

Von Rad, G 1964. Antwort auf Conzelmann's Fragen. ET 7, 388-394. 
-, 1975. Old Testament Theology, vol. I, The Theology of Israel's Historical Traditions. London: SCM Press.

Vriezen, Th. C. 1967. The Religion of Ancient Israel. London: Lutterworth Press.

Waltke, B K \& O'Connor M 1990. An introduction to Biblical Hebrew syntax. Winona Lake, Indiana: Eisenbrauns.

Wenham, G J 1979. Leviticus. Grand Rapids, Michigan: Eerdmans (NICOT).

Zevit, Z 2001. The Religions of Ancient Israel. A Synthesis of Parallactic Approaches. London, New York: Continuum. 